\title{
Kogenud õpetaja praktiline teadmine õpetajakoolituse osana*
}

\author{
Paulien C. Meijer ${ }^{\text {ab1 }}$ \\ ${ }^{\text {a }}$ Radboud University Teacher Academy \\ ${ }^{\mathrm{b}}$ Radboud University Nijmegen
}

\begin{abstract}
Annotatsioon
Õpetaja praktilise teadmise sisusse ja olemusse süüvimine aitab paremini mõista õpetamise keerukust ning võimaldab algajal õpetajal arendada oma teadmisi pedagoogika ja õpetaja praktilise töö vahelistest seostest. Seetõttu on õpetaja praktiline teadmine õpetajatöö alusteadmiste asendamatu osa. Samas on õpetaja praktilise teadmise uurimine näidanud, et kogenud õpetajate teadmised võivad suuresti erineda. Nii ei ole lihtne vastata küsimusele, kuidas oleks võimalik sellist tüüpi teadmist kasutada õpetajakoolituses. Algaja õpetaja suunamine praktiseeriva õpetaja juhendamise alla ei taga automaatselt professionaalsust õpetamisel. Seetõttu kasutavad õpetajakoolitust pakkuvad õppeasutused vähemasti kolme metoodilist lahendust: a) juhtumiuuringuid, b) kogenud õpetajate praktilise teadmise analüüsi ning c) kogenud ja algajate õpetajate ühisõpetamist praktilise teadmise jagamise eesmärgil. Käesolevas artiklis kirjeldatakse, kuidas nimetatud kolmel viisil rakendada õpetaja praktilist teadmist õpetajakoolituses. Artiklis jõutakse järeldusele, et tõelise efekti saavutamiseks professionaalses arengus peavad algajad õpetajad suutma seostada praktilise teadmise nii uurimispõhise teadmisega kui ka neil juba olemasoleva teadmisega ja oma kutsetegevuse perspektiividega.
\end{abstract}

Võtmesõnad: õpetaja praktiline teadmine, õpetajakoolitus, algaja õpetaja, õpetamine, õpetamispraktika

Artikkel on täiendatud ja kohandatud versioon artiklist Meijer, P. C. (2010). The teacher education knowledge base: Experienced teachers' craft knowledge. In E. Baker, P. Peterson \& B. McGaw (Eds.), International Encyclopedia of Education (3rd ed.) (Vol. 7, pp. 642-649). Oxford: Elsevier.

1 P.O. Box 9103, 6500 HD Nijmegen, The Netherlands, p.meijer@docentenacademie.ru.nl 


\section{Õpetaja praktiline teadmine ja selle roll õpetajakoolituses}

Paljud õpetamisalased teooriad ei näi käsitlevat seda, mida õpetajad teavad ja mida nad praktikas teevad. Jääb mulje, et ideed, mida õpetajad peaksid teadma ja mida nad tegelikult teavad, polegi justkui vastavuses. Õpetajakoolituse õppejõud puutuvad sageli kokku üliõpilastega, kes väidavad, et selle vahel, mida neile õpetajakoolituses teoreetiliselt õpetatakse (nt kirjeldatud enam kui kaks aastakümmet tagasi avaldatud Reynoldsi raamatus „Knowledge base for the beginning teacher" (1989)) ning mida kogenud õpetajad teevad ja räägivad, on vähene kooskõla.

Teadlased, kes rõhutavad kogenud õpetajate teadmiste olulisust õpetajakoolituses (nt Grimmett \& MacKinnon, 1992; Lieberman \& Pointer Mace, 2009; Loewenberg Ball \& Cohen, 1999; van Velzen, Volman, Brekelmans, \& White, 2012), lähtuvad eeldusest, et kogenud õpetajad on professionaalid. Professionaalidele on iseloomulik, et nad jagavad ühist teadmisbaasi (vrd Schön, 1983). Selle põhjal eeldatakse, et vähemalt osa kogenud õpetajate teadmisest on omaks võtnud ka teised õpetajad (vrd Meijer, Verloop, \& Beijaard, 1999). Siiski ei olda seda tüüpi teadmise detailides üksmeelel (nt Gholami \& Husu, 2010). Esimene küsimus selles artiklis on, kas on olemas kokkuleppeline teadmisbaas, mida saaks kasvõi osaliselt ammutada sellest, mida kogenud õpetajad teavad (Meijer, Verloop, \& Beijaard, 2001), ning mis aitaks kaasa algajate õpetajate õpetamisoskuste edasisele täiustamisele. Teine küsimus on, kuidas oleks seda võimalik teha. Sobivate meetodite illustreerimiseks toon mõned näited kirjandusest.

Õpetamiseks vajalikku teadmisbaasi on kirjeldatud kõiki õpetajatööks olulisi erialaaspekte hõlmavana (Meijer, 2010; Verloop, van Driel, \& Meijer, 2001). Sellise teadmisbaasi peamine ülesanne on kaasa aidata õpetaja mõtlemisprotsesside praktikapõhisuse (practical arguments) veenvusele. Fenstermacher (1986) väidab, et haridusuuringud peaksid üldjoontes „toetama praktikapõhise käsituse täiustumist õpetajate ja teiste praktikute mõtlemises" (lk 44). Praktikapõhisus osutab uskumustele ja tõekspidamistele, millel põhineb õpetaja tegevus, ning mõjutab Fenstermacheri väitel lõpuks ka õpilase õppimist. Õpetaja mõtlemisprotsess ja selle aluseks olev praktikapõhisus moodustavad keerulise süsteemi, milles peegeldub nende töö olemus. Näiteks väidavad Feiman-Nemser ja Remillard (1996), et õpetaja praktilise teadmise uurimine „väljendab muu hulgas õpetamise kui interaktiivse protsessi keerukust ja ebamäärasust ning ulatuslikult vajadust tegevuse käigus mõtlemise (thinking in action) järele" (lk 76).

Õpetaja (praktiline) teadmine on olnud uurimisobjekt mitu aastakümmet. Enamik neist uurimustest rõhutab seda tüüpi teadmise olulisust uute õpetajate ettevalmistamisel. Algajad õpetajad seisavad silmitsi keerulise 
ülesandega: arendada välja oma praktikapõhine teadmine. Selleks peaks neil olema võimalus tutvuda kogenud õpetajate teadmistega, kuidas kogenud õpetajad toetuvad praktilisele teadmisele õpetamise käigus ning kuidas see teadmine seostub teoreetilisemate arusaamadega õpetamisest. See aitab algajatel õpetajatel arendada oma praktilist teadmist ja selle kaudu ka õpetajatöö oskusi. Beijaard, Meijer, Morine-Dershimer ja Tillema (2005) kirjeldavad, kuidas õpetajatööks vajalike teadmiste omandamine on põimunud kontekstiga, millest see teadmine pärineb, ning rõhutavad, et töötamine koos kogenud õpetaja kui teadmiste allikaga on algaja õpetaja arenguks väga oluline.

Et toetada õpetajakoolituse üliõpilase kujunemist professionaalseks õpetajaks, tuleks Loewenberg Balli ja Coheni (1999) sõnul õpetajakoolituse õppekavades keskenduda neile teadmistele, oskustele ja muudele omadustele, mis on professionaalse õpetamise seisukohast vältimatult vajalikud. LotteroPerdue ja Brickhouse'i (2002) järgi on kutse omandamine võimalik vaid juhul, kui õppijatel on ligipääs eelkäijate kogemustele. See põhimõte õigustab algajate täieõiguslikku liikmelisust praktiseerivates kogukondades (community of practice $)^{2}$. Oma uurimuses jõuavad nad olulisele järeldusele: asjakohane ligipääs teadmistele kogukonnas mängib tähtsat rolli kompetentsuse töökohapõhisel saavutamisel. Asjakohane ligipääs teadmistele kogukonnas seostus nende uurimuses kogukonna kui organisatsiooni arusaamaga, et infot saab ja tuleks omavahel jagada kas suhtluse, otsese kommunikatsiooni või kirjalike allikate vahendusel.

Arusaama õpetaja praktilisest teadmisest käsitletakse kirjanduses mõnevõrra lihtsakoeliselt. Seda tüüpi teadmise uurimisel on lähtutud suurest lugupidamisest õpetajate vastu (nt Elbaz, 1983). Uuringud õpetaja isikliku praktilise teadmise kohta said alguse rahulolematusest sellega, kuidas õpetajat nähti paljudes varasemates õpetamisalastes uurimustes, kus õpetaja teadmine ja tema roll õpetamisel pälvisid vähe tähelepanu. Järgnesid mitmed uuringud, kus õpetajasse kui (praktilise) teadmise kandjasse suhtuti tõsisemalt (nt Cochran-Smith \& Lytle, 1999) ning kus seati eesmärgiks teha õpetamisalastes uurimustes õpetajate "hääl” kuuldavaks. Teised autorid on siiski rõhutanud seda tüüpi teadmise uurimise problemaatilisust ning on mõnikord isegi hoiatanud selle teadmise tõsiselt võtmise eest. Nii väidavad nad näiteks, et õpetaja praktiline teadmine hõlmab fragmentaarseid ja ebatäpseid seisukohti, mis on oma olemuselt ka väga subjektiivsed ning mille seos õpetaja tegeliku praktilise tegevusega on kaheldav. Seetõttu eelistavad

2 Praktiseeriv kogukond on antropoloogide Jean Lave'i ja Etienne Wengeri järgi inimrühm, kes jagab sama oskustööd või ametit. Selles rühmas võib liikmete ühishuvi tõttu toimuda loomulik areng, aga see huvi võidakse ka spetsiaalselt tekitada, et omandada teadmisi valdkonnast. Rühma liikmed ópivad üksteiselt, jagades informatsiooni ja kogemusi rühmas, ning loovad sellega endile võimaluse personaalseks ja professionaalseks arenguks. (Toim.) 
nad keskenduda situatsioonist sõltumatutele väidetele õpetaja teadmise ja käitumise kohta. Enamik õpetajakoolituse õppekavadest sisaldab siiski kombinatsiooni üldisest ja konkreetsetest oludest sõltumatust õpetamisalasest teadmisest ning õpetajate praktilisest teadmisest, mis seostub enamasti ühte või teist sorti mentorprogrammides pakutavaga.

Toetudes paljudele uurijatele õpetajakoolituse valdkonnas, väidan, et õpetajakoolituse seisukohast on oluline mõista õpetaja professionaalse käitumise aluseks oleva teadmise olemust ja sisu. Selles artiklis käsitlen järgmisi küsimusi: mis on seda tüüpi teadmise olemus ja sisu, miks peab see teadmine kuuluma õpetajakoolituse sisusse (teadmisbaasi) ning kuidas oleks võimalik selleni jõuda?

\section{Õpetaja praktilise teadmise olemus ja sisu}

Termin „praktiline teadmine” viitab elutarkusele ja teadmisele, kuidas midagi teha (know-how) ning mille õpetajad omandavad kogemustest ja millele nad toetuvad oma igapäevases õpetamistegevuses. Grimmett ja MacKinnon (1992) nimetavad seda tüüpi teadmist üheks professionaalsuse avaldumise vormiks ja leiavad, nii nagu Schöngi (1983), et see on tegevuse käigus mõtlemise ehk refleksiooni (reflection-in-action) lahutamatu osa. Tegevuse käigus refleksioonil on tähtis koht professionaalses võimekuses ja selle arengus. See viitab vaimsele protsessile, milles praktikud kombineerivad omaenda teadmise elemente, et tulla toime ebamäärastes, ainulaadsetes või keerukates olukordades. Õpetamisel esineb selliseid olukordi pidevalt ja neile tuleb kohe reageerida. See on üks oluline põhjus, miks algajatel õpetajatel tekivad raskused, kui nad püüavad toimida õpetajakoolituses kokku puututud teooriate järgi (vrd Bronkhorst, Meijer, Koster, \& Vermunt, 2011; Hammerness, Darling-Hammond, \& Bransford, 2005). Õpetamissituatsioonid (olukorrad, millega õpetajad kokku puutuvad) on keerulised ja mitmetahulised. Nendega toimetulekuks on vaja mitmekülgseid teadmisi, mis kombineeritakse tervikuks. Samas tuleb sellistes situatsioonides reageerida sekundi murdosa jooksul. Teadmiste integreerimine nii lühikese aja vältel nõuab automatiseerunud oskusi, mida algajatel õpetajatel veel ei ole. See seletab, miks algajad õpetajad suudavad selliseid olukordi analüüsida tagantjärele (st reflekteerida pärast tegevust (reflection-on-action)), kuid neil on raske seda teha õpetamise ajal (st reflekteerida tegevuse käigus, toetudes nende endi kujunevale praktilisele teadmisele). Kuigi algajad õpetajad omandavad teadmised oppetajakoolituses, on nende teadmiste rakendamine tegevuse käigus jätkuvalt probleem õpetama õppimisel.

Õpetajakoolituse õppekavad sisaldavad sageli eraldi ainekursusi mitmesugustest teadmisvaldkondadest, näiteks erialaainet või lapsepsühholoogiat. Ometi nõuab õpetamine, et teadmised neist valdkondadest oleksid 
integreeritud ja neid saaks ühel ajal kasutada. Klassi tagumises pingis istumine ja jälgimine, kuidas kogenud õpetaja toimib, ei too automaatselt kaasa algajal õpetajal sügavamat mõistmist sellest, kuidas erinevad teadmised seotakse õpetamise käigus tervikuks. Veelgi enam, üksnes kogenud õpetaja toimimisviiside kopeerimine päädib tõenäoliselt konservatismiga ${ }^{3}$. Oluline võimalus rakendada õpetaja praktilise teadmise uurimist on pakkuda algajale õpetajale „realistlikult terviklikku pilti õpetamise kognitiivsetest aspektidest" (Clark \& Lampert, 1986), mis oleks midagi enamat kui vastus kuidasküsimusele ja aitaks jõuda miks-küsimuseni, mis on õpetamise aluseks.

Õpetaja praktilisele teadmisele on iseloomulik, et see hõlmab nii uuringupõhiseid/teoreetilisi teadmisi kui ka õpetajate enda praktikast pärit eriteadmisi ning, mis kõige huvitavam, ka teadmist, kuidas need kaks on omavahel seotud. Grimmett ja MacKinnon (1992) väidavad, et õpetajate teadmine tuleneb „kaalutletud reageeringutest praktika oludes ning, kuigi teadmine seostub teadmistega, mida saab õpetada loengusaalis, kujuneb see siiski pikema aja jooksul ópetaja peas refleksiooni tulemusel" (lk 387). Seega annab õpetaja praktiline teadmine infot selle kohta, kuidas kogenud õpetajad seostavad uurimispõhise/teoreetilise teadmise oma õpetamispraktikaga ja vastupidi.

Õpetajakoolituse õppekavu on minevikus palju kritiseeritud selle pärast, et neis oli lõhe teooria (st uurimispõhise teadmise) ja praktika vahel ning need ei suutnud teooriat ja praktikat omavahel ühendada. Õpetajakoolituse õppekavad koosnesid kahest osast: institutsionaalsest osast, mis keskendus teoreetilisele teadmisele, ja õpetajakoolituse praktikast. Katsed neid kahte seostada olid enamasti pealiskaudsed ning jäid üliõpilaste endi ülesandeks. Kogenud õpetaja praktiline teadmine annab infot nende seoste kohta ja ongi just sellises tähenduses väärtuslik. Järgnevalt tutvustan seda, mis on teada õpetaja teadmisest õpetajate praktilise teadmise olemuse ja sisu uuringute kaudu.

\section{Õpetaja praktilise teadmise olemus}

Õpetajate teadmist käsitlevas kirjanduses on kasutatud õpetaja teadmise kohta erinevaid termineid: praktiline teadmine (practical knowledge), ametioskuslik teadmine (craft knowledge), situatiivne teadmine (case knowledge), situatsiooni teadmine (situated knowledge), (isiklik) kutsealane teadmine ((personal) professional knowledge), vaikimisi teadmine (tacit knowledge) jm ${ }^{4}$. Nagu Fenstermacher (1994) märgib, ei osuta need terminid ilmtingimata

Teatud metoodiliste võtete pimesi omaksvõtmine. (Toim.)

4 Need terminid on levinud inglise keeles ja eestikeelsed vasted on osaliselt provisoorsed.

(Toim.) 
erinevatele teadmistüüpidele, vaid pigem asjaolule, et nende kasutuskontekstid on erinevad. Suur osa õpetaja praktilise teadmise käsituste erinevustest on seletatav, kui välja selgitada seda tüüpi (ühte või teist liiki) teadmise lähtealused. Selle kontseptsiooni uuringute (vrd Meijer, 1999) põhjal saab välja tuua mitmeid õpetajate praktilise teadmise karakteristikuid. Praktiline teadmine:

a) on isiklik, st iga õpetaja teadmine on teatud ulatuses ainulaadne;

b) on kontekstist sõltuv, st on defineeritud klassis toimuvana ja sellele kohandatuna;

c) põhineb kogemusel (tegevuse reflekteerimisel), mis osutab pärinemisele ja kujunemisele praktilisest kogemusest;

d) on õpetamispraktika aluseks;

e) on peamiselt vaikiv, st paljud õpetajad ei ole harjunud oma teadmisi sõnastama;

f) on ühelt poolt seotud õpetamispraktikaga ja teisalt uurimispõhiste/ teoreetiliste teadmistega;

g) on sisupõhine, mis tähendab, et see seostub õpetatava ainega.

Viimasest aspektist - õpetaja praktilise teadmise seotusest õpetatava ainega - tulenevad mitmed olulised järeldused, kuidas seda teadmistüüpi lülitada õpetajakoolitusse. Vajadus selle järele muutub veelgi tuntavamaks, kui vaatluse alla võetakse õpetaja praktilise teadmise sisu.

\section{Oppetaja praktilise teadmise sisu}

Mitmetes õpetaja praktilise teadmise uurimustes on teadlased keskendunud õpetaja praktilise teadmise sisule, pakkudes välja kategooriaid, mis hõlmavad õpetaja teadmisi ja uskumusi. Shulman (1987) oli üks esimesi, kes uuris õpetajate teadmise tüüpe, mis on õpetajate tegevuste aluseks. Ta pakkus välja õpetaja teadmise valdkonnad ja kategooriad, mida teised uurijad on kasutanud, laiendanud ja täiendanud. Need kategooriad on:

a) ainealane teadmine (content knowledge);

b) üldine pedagoogiline teadmine (general pedagogical knowledge), mis viitab klassi juhtimise ja organiseerimise üldprintsiipidele ning strateegiatele, mis väljuvad õppeaine piiridest;

c) õppekava teadmine (curriculum knowledge) erilise rõhuasetusega materjalidel ja programmidel, mis on õpetaja „tööriistadeks”;

d) óppesisu pedagoogiline teadmine (pedagogical content knowledge), mis on sulam ainealasest teadmisest ja pedagoogikast ning mis kuulub vaid õpetajatele, on nende spetsiifiline professionaalse arusaamise viis;

e) teadmised õpilastest ja nende eripärast; 
f) hariduskonteksti teadmine (knowledge of educational contexts), mis ulatub rühma või klassiga töötamisest, koolipiirkonna juhtimisest ja rahastamisest ühiskonna ja kultuuri eripärade tundmiseni;

g) teadmine hariduse eesmärkidest ja väärtustest, nende filosoofilistest ja ajaloolistest alustest.

Selle valdkonnaga seostuvad uurimused on enamasti läbi viidud mõne spetsiifilise õppeaine kontekstis, nagu inglise keel, sotsiaalained, matemaatika ja loodusained. Eriti kipub teemaga seotuks jääma õppesisu pedagoogilise teadmise käsitus gümnaasiumiastme loodusainetes ja see näib viitavat peamiselt teadmistüübile, mis seostub otseselt õpetaja tegeliku praktikaga õppeaine õpetamisel. Paljude seniste uurimuste puhul võib märgata, et õpetaja praktilise teadmise sisu vaadeldakse kui erinevate teadmiskategooriate lõimingut. See on kooskõlas Grimmeti ja MacKinnoni (1992) ametioskusliku teadmise definitsiooniga, millest selgub, et see teadmine hõlmab teiste teadmiste elemente, mida eristavad Shulman ja tema järgijad. Grimmeti ja MacKinnoni väitel on ametioskuslik teadmine oma põhiolemuselt õpetaja omandatud tarkus, mis on seotud tema arusaamaga paljudest õpetamisprobleemidest. Tegemist on aruka ja tundliku teadmisega sellest, kuidas midagi teha (know-how) tegevussituatsioonis. See on „... spetsiifiline kõlbeliselt kohase ja tundliku oskusteabe vorm, mille on loonud õpetajad ... oma töökogemuste ja läbielatu põhjal ning mis puudutab ainega seotud ja õppijakeskse pedagoogika küsimusi” (lk 396).

Osa õpetaja ametioskuslikust teadmisest ehk praktilisest teadmisest on seega teadmine erinevatest valdkondadest. Kõikidel õpetajatel on teadmine õpilastest, õppesisust, õppekavast jms. Mitmetes uurimustes ilmnenud erinevused puudutavadki seda, mida õpetajad neist valdkondadest teavad ja kuidas nad loovad nende põhjal oma teadmise. Paljud uurijad kirjeldavad neid erinevusi teadmistüüpe klassifitseerides, mille puhul on õpetaja praktiline teadmine avatud sarnaste kategooriatena (sageli põhinevad Shulmani kategooriatel, mida on kirjeldatud ülal). Kategooriate sisu ja viis, kuidas nad omavahel seostuvad, on üsna sarnased eristatavate tüüpide raames, kuid tüüpide vahel on märkimisväärsed erinevused. Illustreerimaks neid erinevusi, on tabelis 1 kirjeldatud kolme õpetaja praktilise teadmise avaldumist kategooria „Õpilase õppimine ja arusaamine” kohta. Kirjeldused pärinevad kvalitatiivsest uuringust, mille viisin läbi kogenud õpetajatega, et uurida nende praktilist teadmist teksti mõistmise õpetamisest 16-18-aastastele õpilastele (Meijer, 1999). Parempoolne veerg kajastab kolme õpetaja tsiteeringuid, mis nätlikustavad leitud erinevusi. Teistest kvalitatiivsetest uuringutest ilmnevad sarnased mustrid õpetaja praktilises teadmises (või praktilises teadmises, õppesisu pedagoogilises teadmises jm). 


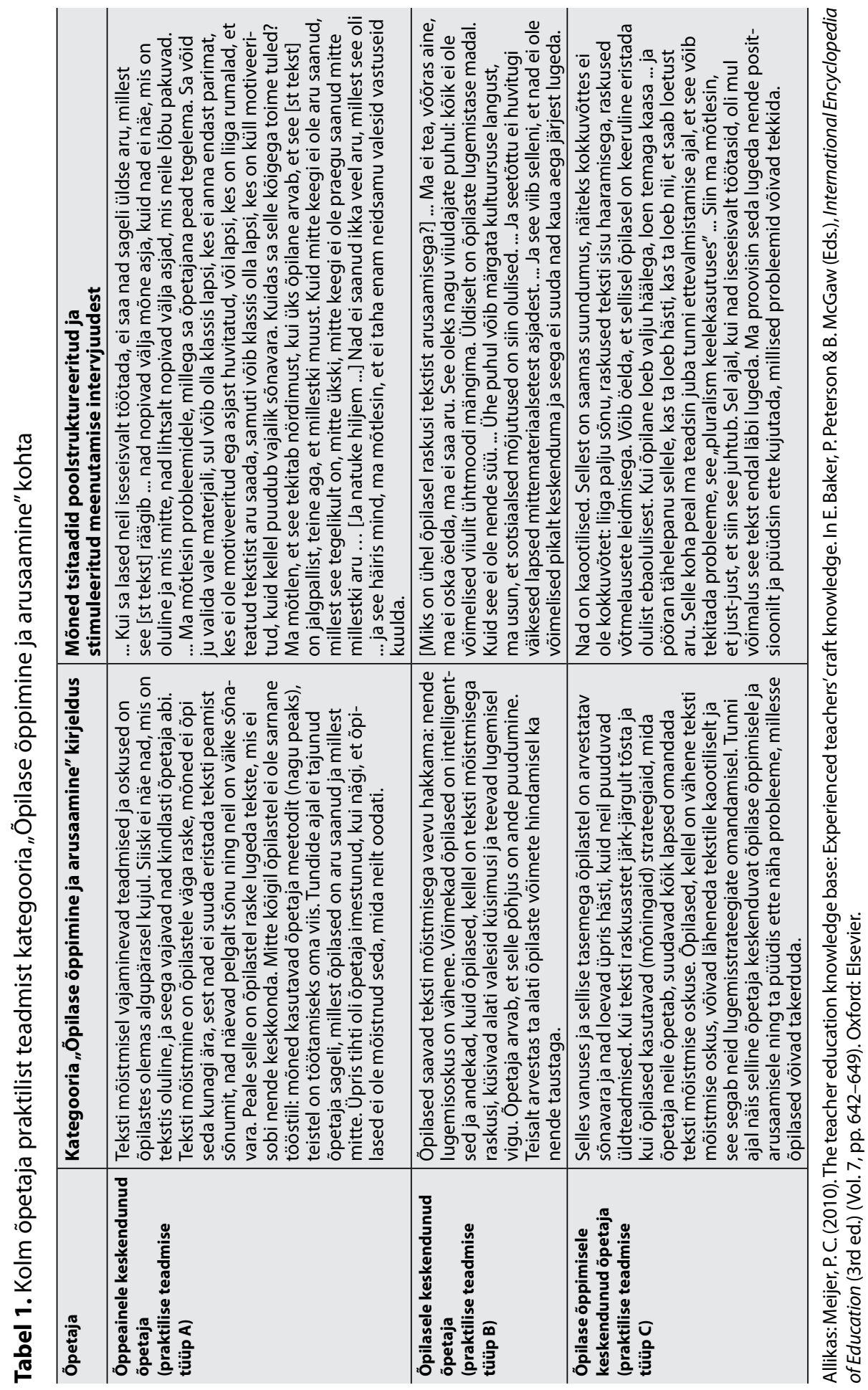


Kokkuvõtteks võib öelda, et õpetaja praktilise teadmise uurimused osutavad selle teadmistüübi ühisjoontele, kuid ka olulistele erinevustele, mis kajastavad selle idiosünkraatilist iseloomu. Selline mitmekesisus ja idiosünkraatilisus võivad raskendada õpetamise aluseks oleva praktilise teadmise uurimist, eriti kui eesmärgiks on kaasata see teadmistüüp õpetajakoolituse sisusse. Kuna õpetaja praktiline teadmine on oma olemuselt idiosünkraatiline, siis ei ole olemas üht ja ainuõiget kaasamisviisi. Järgmises alajaotises käsitlen kirjanduse põhjal mõningaid strateegiaid, mille abil saab praktilise teadmise lülitada õpetajakoolituse sisusse.

\section{Kogenud õpetaja praktilise teadmise kaasamine õpetajakoolitusse}

Leinhardt (1990) kirjeldab praktilist teadmist kui informatsiooni rikkust, mis on väga kogenud praktiseerijatel olemas tänu enda praktilisele õpetamistööle. Ta väidab, et seda tüüpi teadmine tuleb siduda teooriaga, sest nii on võimalik saavutada terviklik, usaldusväärne õpetaja hindamine. Peale õpetajate hindamise on vaja ühendada õpetaja (eksperdi) praktiline teadmine uurimispõhiste teooriatega, eriti õpetajakoolituse valdkonnas. Küsimus on selles, kuidas õpetaja praktilisele teadmisele ligi pääseda ja seda töödelda, toetamaks algaja õpetaja professionaalset arengut. Et mõista, mida algaja õpetaja peaks õppima, on Hammerness jt (2005) esmalt väitnud, et „tarkust ei saa õpetada" (lk 371). Õpetajad-eksperdid ei saa oma teadmisi edasi anda lihtsalt sel moel, mis võimaldaks algajatel õpetajatel neid kohe rakendada - seda tüüpi teadmine on oma olemuselt vaikiv. Teiseks on Hammerness jt kirjeldanud, et olemasolevaid teadmisi ei osata alati tegevuses kasutada. Oppetajad ei rakenda (nt kursustel omandatud) teadmisi automaatselt praktikas ettetulevate probleemide lahendamisel. Arvestades neid kaht asjaolu, ei peaks rõhuasetus olema mitte neil teadmistel, mis on õpetajatel oma õpetamise kohta, vaid teadmistel, mis kuuluvad nende õpetamise juurde ja mis mõjutavad otseselt nende tegevust. See on väga oluline eeldus, millest õpetaja praktiline teadmine lähtub: õpetaja teadmine avaldub tema ópetamises. Schön (1983) väidab, et professionaalide praktika mõistmiseks peame mõistma neid teadmisi, mida nad oma tegevuses kasutavad. Seda võib võrrelda Leinhardti ideega (1988), et õpetaja teadmist peab uurima ka praktikas, mõistmaks õpetamisprotsessi keerukust. Leinhardti sõnul peaks õpetaja tunnetusprotsesse (teacher's cognition) ja tegevusi uurima õpetamise ajal, sest sel hetkel on teadmine ja tegevus lahutamatud. Brown, Collins ja Duguid (1989) väidavad, et kõik teadmised luuakse tegudes ja situatsioonides. Seega sisaldub teadmine tegudes, või nagu 
sedastab Leinhardt (1988), „see on kinnistunud konteksti artefaktidesse” (lk 148). Browni jt väitel toob see kaasa vajaduse uurida teadmist kasutussituatsioonis. Nad on seisukohal, et teadmise uurimine võib olla asjakohatu või isegi vigane, kui see teadmine on eraldatud kasutusviisist.

Oppetaja praktilise teadmise kaasamisel õpetajakoolitusse võib olla erinevaid vorme. Kõige radikaalsem on näiteks Haggeri ja McIntyre (2006) kirjeldatud koolikeskkonnas toimuv õpetajate väljaõpe: tulevased õpetajad saavad ettevalmistuse peamiselt koolides, mitte õpetajakoolituse õppeasutustes. Üha suuremat tähelepanu pööratakse koolile kui algaja õpetaja õppimiskohale. See peegeldub ka arvukates publikatsioonides selle kohta, kuidas õpetajakoolituse üliõpilane või algaja õpetaja õpib koolikeskkonnas või töökohal (nt van Velzen et al., 2012). Selles kontekstis peetakse oluliseks kogenud õpetaja praktilise teadmise sidumist õpetajakoolitusega, millest võivad lähtuda erinevad strateegiad. Esiteks, algajad õpetajad saavad ligipääsu kogenud õpetajate praktilisele teadmisele, mida on varem uuritud, nt esitatud (mitmete) juhtumiuuringute või tüpoloogiatena, nagu näidatud tabelis 1 . Teiseks, algajad õpetajad võivad ka ise uurida kogenud õpetajate praktilist teadmist. Allpool olen toonud mõned näited, kuidas seda teadmist on võimalik ühendada õpetajakoolitusega ja mis tingimused peavad olema selleks täidetud.

\section{Õpetaja praktilise teadmise kasutamine õpetajakoolituses}

Mitmed uurimused näitavad, et õpetaja praktilise teadmise sisu detailne kirjeldamine on algajale õpetajale tähtis. Uurijad ja õpetajakoolitajad on esitanud soovitusi, kuidas rakendada õpetajakoolituses selliseid kirjeldusi näiteks juhtumite, narratiivide või lugudena. Sellega seoses kirjeldavad Hammerness jt (2005) „õpetamise analüüsi” kui õpetajakoolituse olulist tegurit. Juhtumid ei hõlma üksnes kirjapandud juhtumeid, vaid need sisaldavad ka videoid õpetamistegevustest. Andmebaase videosalvestistega õpetamisest klassiruumis leidub paljudes õpetajakoolituse õppeasutustes, nt Michigani ülikoolis, Carnegie Foundation's Gallery of Teaching and Learningis (http://www. carnegiefoundation.org/resources/gallery-teaching), California ülikooli New Teacher Centeris (http://www.newteachercenter.org/) Santa Cruzis. Lisaks on olemas Teachers College Recordi digitaalne väljapanek (http://www. tcrecord.org/makingteachingpublic/) veebilehtedest, kus on kasutatud multimeediat klassiruumi õppeprotsessi salvestamiseks California, Philadelphia ja New Yorgi alg- ja keskkoolide matemaatika, keeleõppe (inglise keele) ja sotsiaalainete tundides. Nimetatud andmebaasides leidub intervjuusid õpetajatega, kes kommenteerivad oma tundide videoid, põhjendades tehtud valikuid. Lisaks on esitatud lingid asjakohastele teooriatele. Nii on algajatel 
õpetajatel ligipääs paljudele õpetamistegevustele ning nad saavad infot selle kohta, millistele teadmistele toetub õpetamine nähtud videokatkendis ja kuidas õpetamine on seotud asjakohaste teooriatega (st uurimispõhiste teadmistega).

\section{Stimuleeritud meenutamine kui õpetaja praktilise teadmise väljendamise meetod}

Õpetaja praktilise teadmise uurimine hõlmab mitmeid loomingulisi meetodeid, nt erinevaid intervjuutehnikaid, ideekaarte, tagasisidet videote kohta, mis kutsuvad esile seda tüüpi teadmist. Tähelepanu vääriv mõõtevahend on stimuleeritud meenutamise intervjuu. Stimuleeritud meenutamise intervjuus selgitavad õpetajad, mida nad mõtlesid videosse võetud tunni ajal, mille nad just läbi viisid. Sellisel moel saadud info seostub tihedasti Schöni ideega teadmisest tegevuse ajal (knowing-in-action) ning Leinhardti vastulausega uurida õpetaja teadmist praktikas. See mõõtevahend pärineb Bloomi uuringutest (1953) ja seda on sestpeale kasutanud erinevad uurijad.

Mõõtevahendi kasutamine võimaldab algajal õpetajal analüüsida kogenud õpetaja praktilist teadmist. Stimuleeritud meenutamise intervjuu on tegelikult valjusti mõtlemise tehnika asendus. Nii huvitav kui valjusti mõtlemise tehnika õpetaja mõtlemise uurimise vahendina ka ei tundu, ei saa seda siiski ainetunnis rakendada, sest see häiriks tundi. Stimuleeritud meenutamise intervjuus kasutatakse videot tunnist, mille õpetaja on just andnud. See aitab õpetajal meenutada tema enda interaktiivseid mõtteid tunni ajal ning stimuleerib teda tundi uuesti läbi elama. Stimuleeritud meenutamise intervjuu võimaldab õpetaja varjatud mõtlemist nähtavaks muuta ja selgitada välja tunnetusprotsesse, mis on nende vaadeldava tegevuse taga. Sellist tunnetust on iseloomustatud järgmiselt (vrd Meijer, Beijaard, \& Verloop, 2002):

a) see on sekundi murdosa jooksul tekkiv mõte;

b) see on seotud spetsiifilise kontekstiga (st ainetunniga);

c) see on tihedasti seotud õpetaja teadmiste ja uskumustega ühelt poolt

ning klassiruumi praktikaga teiselt poolt;

d) see on oma olemuselt integreeritav.

Need tunnusjooned võivad olla probleemsed, kui eesmärk oleks anda objektiivseid selgitusi õpetaja tunnetusprotsesside kohta õpetamise ajal üldiselt, kuid need on seda huvipakkuvamad algajatele õpetajatele, kes püüavad mõista, mis klassiruumis tegelikult toimub.

Stimuleeritud meenutuse meetodit on õpetajakoolituses võimalik kasutada mitmeti. Näiteks kirjeldavad Ethell ja McMeniman (2000) viisi, kuidas 
saab süstemaatiliselt planeerida selle meetodi kasutamist õpetajakoolituse kontekstis. Nad arendasid välja sekkumise „Meisterliku õpetamise aluseks olevate mõtete nähtavaks muutmine ja sellele juurdepääsu saavutamine", mis sisaldas neljast sammust koosnevat töötubade seeriat algajatele õpetajatele:

1. samm: vaatlemine ja järeldamine;

2. samm: isiklike teooriate nähtavaks muutmine;

3. samm: meisterõpetaja tegevusele järgnev refleksioon (st stimuleeritud meenutamise intervjuul antud vastused);

4. samm: algajate ja kogenud õpetajate refleksioonide vastandamine.

Meijer, Zanting ja Verloop (2002) kirjeldasid samuti stimuleeritud meenutamise intervjuud kui vahendit, mis võimaldab algajal õpetajal sõnastada oma kogenud mentori praktilist teadmist. Nad kirjeldasid, millist väärtust pakub algajale õpetajale kogenud õpetaja praktilise teadmise süstemaatiline uurimine, ja võrdlesid seda muu hulgas aknaga, mis tagab juurdepääsu vaadeldava õpetamise taga olevatele mõtetele. Lisaks võimaldab see seostada need mõtted teoreetiliste ja enam abstraktsete mõistetega, millega algaja õpetaja õpetajakoolituses kokku puutub.

\section{Praktilise teadmise jagamine ühisõpetamise abil}

Viimasel ajal ilmunud kirjanduses leidub teisigi uuenduslikke praktikaid, mis võimaldavad algajal õpetajal saada osa õpetaja praktilisest teadmisest. Näiteks uurisid van Velzen, Volman ja Brekelmans (artikkel on avaldamisel) mentorõpetaja ja algaja õpetaja ühisõpetamist praktilise teadmise jagamise eesmärgil. Nende käsitlus hõlmas kolmest tunnist koosnevat seeriat, kus ühisõpetamist rakendati teise tunni ajal. Tundidele eelnenud ja järgnenud vestlused olid osa nende käsitlusest, samuti tundidele eelnev arupidamine, milles keskenduti algaja õpetaja õppimisvajadustele. Uurijad leidsid, et praktilise teadmise kujundamine ja arendamine nõuavad kogenud õpetajat, kes on oma käitumisega eeskujuks ning suudab sõnastada ka oma vaikimisi teadmist: „Ühisõpetamine võimaldab jagada kogemusi, mistõttu on mentoril lihtsam arutleda oma tegevuse ja selle põhjuste üle." See osutus võimalikuks vaid siis, kui pärast tundi toimunud vestluse ajal arutleti otsesõnu selle üle, kuidas ja miks oli mentor just nii käitunud. Mentorid reflekteerisid koos algajate õpetajatega, mida nad olid teinud ja öelnud ning kuidas see mõjutas algajaid õpetajaid ja nende praktilise teadmise arengut. 


\section{Järeldused}

Kogenud õpetaja praktilise teadmise uurimise kaudu mõistab algaja õpetaja paremini teiste õpetajate ja enda õpetamist, sest see võimaldab tal a) kogeda õpetaja praktilise teadmise ja tema õpetamise vahelist seost, b) uurida (kogenud) õpetaja praktilise teadmise ja õpetajakoolituses omandatud teoreetilisemate seisukohtade vahelist seost ning c) mõista teiste õpetajate ja nende (areneva) praktilise teadmise vahelist seost. Sellest arusaamine aitab algajal õpetajal arendada enda õpetamist palju teadlikumal viisil, sest ta õpib mõtestatult märkama õpetamise käigus tehtud valikuid.

Õpetaja praktilise teadmise kaasamiseks õpetajakoolituse alusteadmistesse peavad olema täidetud järgmised tingimused. Teadmine peab:

a) kuuluma õpetaja tegevusaegse teadmise juurde;

b) olema seotud algaja õpetaja enda (areneva) praktilise teadmisega;

c) olema seotud ka uurimispõhiste teadmiste ja teooriatega;

d) olema seotud algaja õpetaja edasiste tegevuste ja praktikapõhisusega.

On selge, et kogenud õpetaja praktiline teadmine on vaid üks allikas, millest algaja õpetaja saab õpetajakoolituse raames õppida. Nagu selles artiklis kirjeldatud, pakub see väärtuslikku sissevaadet õpetamise keerukuse mõistmisse ja aitab kaasa algaja õpetaja professionaalsele arengule. Siiski peab arvesse võtma „tegevuse konservatiivsuse” printsiipi, mida on kirjeldanud näiteks Loewenberg Ball ja Cohen (1999), van Velzen jt (2012), ning protsessi, mida on käsitlenud Zeichner ja Tabachnick (1981): igapäevase koolielu kogemused ja kogenud kolleegidega peetud vestlused „uhuvad minema” algajate õpetajate liberaalsed ja progressiivsed seisukohad, millega nad on kokku puutunud õpetajakoolituses.

Üks olulisemaid õppimisprotsessi komponente on see, kuidas õppida praktika käigus ja põhjal. Teooria ja praktika sidumine on ülitähtis. Algajad õpetajad peavad oppima erinevaid strateegiaid, kuidas siduda teooriat ja praktikat. Kogenud õpetaja praktiline teadmine on selles protsessis vaid üks, kuid äärmiselt väärtuslik allikas.

\section{Kasutatud kirjandus}

Beijaard, D., Meijer, P. C., Morine-Dershimer, G., \& Tillema, H. (2005). Trends and themes in teachers' working and learning environment. In D. Beijaard, P. C. Meijer, G. Morine-Dershimer \& H. Tillema (Eds.), Teacher professional development in changing conditions (pp.9-23). Dordrecht:Springer. http://dx.doi.org/10.1007/1-4020-3699-X_1 Bloom, B. S. (1953). Thought processes in lectures and discussions. Journal of General Education, 7(3), 160-169. 
Bronkhorst, L., Meijer, P. C., Koster, B., \& Vermunt, J. D. (2011). Fostering meaningoriented learning and deliberate practice in teacher education. Teaching and Teacher Education, 27(7), 1120-1130. http://dx.doi.org/10.1016/j.tate.2011.05.008

Brown, J. S., Collins, A., \& Duguid, P. (1989). Situated cognition and the culture oflearning. Educational Researcher, 18(1), 32-42. http://dx.doi.org/10.3102/0013189X018001032

Clark, C., \& Lampert, M. (1986). The study of teacher thinking: Implications for teacher education. Journal of Teacher Education, 37(5), 27-31. http://dx.doi.org/10.1177/002248718603700506

Cochran-Smith, M., \& Lytle, S. L. (1999). Relationships of knowledge and practice: Teacher learning in communities. In A. Iran-Nejad \& C. D. Pearson (Eds.), Review of Research in Education (Vol. 24, pp. 249-305). Washington: AERA.

Elbaz, F. (1983). Teacher thinking: A study of practical knowledge. New York: Nichols Publishing Company.

Ethell, R. G., \& McMeniman, M. M. (2000). Unlocking the knowledge in action of an expert practitioner. Journal of Teacher Education, 51(2), 87-101. http://dx.doi.org/10.1177/002248710005100203

Feiman-Nemser, S., \& Remillard, J. (1996). Perspectives on learning to teach. In F. B. Murray (Ed.), The teacher educator's handbook. Building a knowledge base for the preparation of teachers (pp. 63-91). San Francisco: Jossey-Bass.

Fenstermacher, G. D. (1986). Philosophy of research on teaching: Three aspects. In M. C. Wittrock (Ed.), Handbook of research on teaching (3rd ed.) (pp. 37-49). New York: MacMillan.

Fenstermacher, G. D. (1994). The knower and the known: The nature of knowledge in research on teaching. Review of Research on Teaching, 20, 3-56.

Gholami, K., \& Husu, J. (2010). How do teachers reason about their practice? Representing the epistemic nature of teachers' practical knowledge. Teaching and Teacher Education, 26(8), 1520-1529. http://dx.doi.org/10.1016/j.tate.2010.06.001

Grimmett, P. P., \& MacKinnon, A. M. (1992). Craft knowledge and the education of teachers. Review of Research in Education, 18(1), 385-456. http://dx.doi.org/10.2307/1167304

Hagger, H., \& McIntyre, D. (2006). Learning teaching from teachers: Realizing the potential of school-based teacher education. Maidenhead, Open University Press / McGraw-Hill.

Hammerness, K., Darling-Hammond, L., \& Bransford, J. (2005). How teachers learn and develop. In L. Darling-Hammond \& J. Bransford (Eds.), Preparing teachers for a changing world: What teachers should learn and be able to do (pp. 358-389). San Francisco: Jossey-Bass.

Leinhardt, G. (1988). Situated knowledge and expertise in teaching. In J. Calderhead (Ed.), Teachers' professional learning (pp. 146-168). London: Falmer Press. http://dx.doi.org/10.3102/0013189X019002018

Leinhardt, G. (1990). Capturing craft knowledge in teaching. Educational Researcher, $19(2), 18-25$.

Lieberman, A., \& Pointer Mace, D. H. (2009). The role of „accomplished teachers” in professional learning communities: Uncovering practice and enabling leadership. Teachers and Teaching: Theory and Practice, 15(4), 459-470.

http://dx.doi.org/10.1080/13540600903057237 
Loewenberg Ball, D., \& Cohen, D. K. (1999). Developing practice, developing practitioners. Toward a practice-based theory of professional education. In L. DarlingHammond \& G. Sykes (Eds.), Teaching as the learning profession (pp. 3-32). San Francisco: Jossey-Bass.

Lottero-Perdue, P. S., \& Brickhouse, N. W. (2002). Learning on the job: The acquisition of scientific competence. Science Education, 86(6), 756-782.

http://dx.doi.org/10.1002/sce.10034

Meijer, P. C. (1999). Teachers' practical knowledge. Teaching reading comprehension in secondary education. (Doctoral dissertation). Leiden University, Leiden.

Meijer, P. C. (2010). The teacher education knowledge base: Experienced teachers' craft knowledge. In E. Baker, P. Peterson \& B. McGaw (Eds.), International Encyclopedia of Education (3rd ed.) (Vol. 7, pp. 642-649). Oxford: Elsevier. http://dx.doi.org/10.1016/B978-0-08-044894-7.00639-4

Meijer, P. C., Beijaard, D., \& Verloop, N. (2002). Examining teachers' interactive cognitions using insights from research on teachers' practical knowledge. In C. Sugrue \& C. Day (Eds.), Developing teachers and teaching practice (pp. 162-178). London: Routledge/Falmer. http://dx.doi.org/10.1016/S0742-051X(98)00045-6

Meijer, P. C., Verloop, N., \& Beijaard, D. (1999). Exploring language teachers' practical knowledge about teaching reading comprehension. Teaching and Teacher Education, 15(1), 59-84.

Meijer, P. C., Verloop, N., \& Beijaard, D. (2001). Similarities and differences in teachers' practical knowledge about teaching reading comprehension. Journal of Educational Research, 94(3), 171-184. http://dx.doi.org/10.1080/00220670109599914

Meijer, P. C., Zanting, A., \& Verloop, N. (2002). How can student teachers elicit experienced teachers' practical knowledge? Tools, suggestions and significance. Journal of Teacher Education, 53(5), 406-419. http://dx.doi.org/10.1177/002248702237395

Reynolds, M. C. (1989). Knowledge base for the beginning teacher. Oxford: Pergamon.

Schön, D. A. (1983). The reflective practitioner: How professionals think in action. New York: Basic Books.

Shulman, L. S. (1987). Knowledge and teaching: Foundations of the new reform. Harvard Educational Review, 57(1), 1-22.

Van Velzen, C., Volman, M., \& Brekelmans, M. (submitted). Modelling and scaffolding in co-teaching: Mentoring tools in guided work-based education.

Van Velzen, C., Volman, M., Brekelmans, M., \& White, S. (2012). Guided work-based learning: Sharing practical teaching knowledge with student teachers. Teaching and Teacher Education, 28(2), 229-239. http://dx.doi.org/10.1016/j.tate.2011.09.011

Verloop, N., van Driel, J. H., \& Meijer, P. C. (2001). Teacher knowledge and the knowledge base of teaching. International Journal of Educational Research, 35(5), 441-461. http://dx.doi.org/10.1016/S0883-0355(02)00003-4

Zeichner, K. M., \& Tabachnick, B. R. (1981). Are the effects of university teacher education „washed out” by school experience? Journal of Teacher Education, 17(3), 7-11. http://dx.doi.org/10.1177/002248718103200302 


\title{
Experienced teachers' practical knowledge as part of teacher education
}

\author{
Paulien C. Meijer ${ }^{\text {ab1 }}$ \\ ${ }^{a}$ Radboud University Teacher Academy \\ ${ }^{\mathrm{b}}$ Radboud University Nijmegen
}

SUMMARY

Insight into the content and nature of teachers' practical knowledge contributes to a better understanding of the complexities of teaching and, as such, helps student teachers to develop knowledge about the relationship between educational theories and teaching practice. For this reason, teachers' practical knowledge is an indispensible part of the knowledge base for teaching. However, research on teachers' practical knowledge shows enormous variety in what experienced teachers know. As a result, the question of how this type of knowledge can be included in teacher education is not easily answered. Simply placing student teachers under the care of practicing teachers is not automatically enough. The first question addressed in this article is whether there is an agreed-upon knowledge base that can - at least partly - be derived from the content of what experienced teachers know, and which can contribute to further enhancing beginning teachers' teaching practice. The second question is how this might be done.

First, this article describes the nature of teacher practical knowledge as: personal, contextual, based on (reflections on) experience, underlying teaching practice, mainly tacit, related to teaching practice, but also to researchgenerated knowledge, and content-related. Second, the content of teachers' practical knowledge is described as a combination of: content knowledge, general pedagogical knowledge, curriculum knowledge, pedagogical content knowledge, knowledge of learners, knowledge of educational contexts and knowledge of educational ends (e.g. Shulman, 1987). Reviewing the results of studies on teachers' practical knowledge show common features in this type of knowledge, but also substantive differences, reflecting that this type of knowledge is idiosyncratic by nature. This variety and idiosyncrasy may pose problems as well as challenges in the search for practical knowledge underlying teaching, particularly when the aim is to incorporate this type of knowledge into teacher education. There is no one straightforward way to

P.O. Box 9103, 6500 HD Nijmegen, The Netherlands, p.meijer@docentenacademie.ru.nl 
do so when the idiosyncratic nature of teachers' practical knowledge is taken into account.

Given these characteristics and problems, this article outlines three ways in which teacher education institutions in general attempt to deal with this. These are (a) using cases, (b) having student teachers investigate experienced teachers practical knowledge, and (c) having experienced teachers and student teachers teach collaboratively to share their practical knowledge. In all these pedagogies, involving experienced teachers' practical knowledge is seen as crucial. First, using cases allows student teachers to can gain access to experienced teachers' practical knowledge that has been examined by others and, for example, written down in (multiple) case studies or typologies. Second, student teachers might investigate experienced teachers' practical knowledge themselves by following interview procedures in dialogue with their mentor teacher. And third, „co-teaching” involving a mentor teacher and the student teacher is described as a potentially powerful means of sharing practical knowledge. This article describes these three ways of including teachers' practical knowledge in teacher education in more detail.

The article concludes that to be of explicit value, student teachers need to relate this type of knowledge to other research-generated knowledge, their own knowledge and their future actions. Examining and sharing experienced teachers' practical knowledge provides student teachers with opportunities to better understand other teachers' teaching and their own teaching by (a) experiencing the relationship between a teacher's practical knowledge and his or her teaching, (b) exploring the relationship between (experienced) teachers' practical knowledge and more theoretical notions they learn about in teacher education, and (c) learning about the relationship between other teachers' practical knowledge and their own (developing) practical knowledge. Such an understanding can help student teachers develop their own teaching in a more conscious way, as they learn to underpin the choices they make in their teaching more thoughtfully.

One of the most essential components of the process of learning to teach is learning how to learn in and from practice. Linking theory and practice is vital. Student teachers need to learn various strategies for linking theory and practice. This article described how experienced teachers' practical knowledge may only be one resource, but it is an extremely valuable resource in this process.

Keywords: teachers' practical knowledge, teacher education, student teacher learning, complexities of teaching, teaching practice 